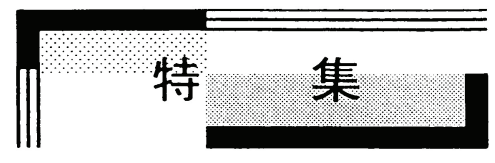

\title{
沿岸多段砂州システムの組織的・大規模長期変動の特性*
}

\section{A Long-Term Field Observation of Systematic Behaviors of Multiple Longshore Bars}

\author{
由 比 政 年** \\ YUHI Masatoshi
}

\author{
楳田 真 也 ${ }^{* *}$ \\ UMEDA Shinya
}

\begin{abstract}
The variabilities of multiple bar system have been investigated in inter-annual time scale based on long-term field surveys. The field sites include Ishikawa Coast and Chirihama Coast facing the Sea of Japan. On both sites, large scale sandbar system has developed and the morphological variabilities are characterized by cyclic and systematic migration of multiple bars. On Ishikawa Coast, representative spatial patterns during individual cycle are analyzed to describe the three-dimensional morphological evolutions. Considerable changes in plan shape are observed such as quasi-regular crescentic patterns, parallel alignment of oblique bars, disconnection and realignment of bars. In contrast, bar migration on Chirihama Coast is quasi two-dimensional. The transition of the multiple sandbar systems is well reproduced by an empirical parametric model.
\end{abstract}

Keywords: Sandbar, Migration, Long-term variability, Cyclic behavior, Parametric model

\section{1. 緒 言}

沿岸砂州は, 国内外の多くの砂浜海岸において 汀線に平行に発達する浅瀬地形であり、海浜地形 システムの時空間変動を特徵付ける基幹要素の 1 つである。沿岸砂州の発達規模や配置は、外浜 の地形変動を特徴づけることに加え, 砕波過程へ の影響を通じて前浜地形変化とも関連する。また、 水深の浅い砂州頂部付近では砕波が促進されて 天然の防波堤として機能し、トラフ部分は稚魚・ 稚貝の生息域となるなど、沿岸砂州は自然と共生 した海岸防災や生態環境再生を考える上で中核 的役割を担っている。従来、多くの研究により、 沿岸砂州の時空間変動に関する基本特性の解明 が進められてきたが（例えば、[1, 2]）、多様な時 空間スケールを有するその動態には未解明な点 も多く残されている。

沿岸砂州の動態に関して、近年、世界数地点に おいて、長期時間スケールを有する、沿岸砂州の 組織的沖向き移動の存在が観察されてきた (例え
ば、[3 - 9])。Net Offshore Migration （NOM）と 称されるこの種の大規模変動は周期的であり、砂 州の形成・沖向き移動・消失で構成されるサイク ルが、数年〜20 年程度の再現周期で繰り返され る。その再現周期は地域により異なるものの、砂 州配置の変遷形態はおよそ共通であり、一連のサ イクルにおいて、砂州は汀線近傍で形成され、沖 向きに移動しながら最大規模に発達した後に、さ らに沖向きに移動して減衰・消失する。最も沖側 に位置する砂州が消失すると、1つ岸寄りに位置 していた次の世代の砂州が引き続き沖向き移 動・発達を開始する。

日本国内においても、同様の現象が太平洋沿岸 に位置する茨城県波崎海岸（例えば、[6]）や日本 海に面した石川海岸, 千里浜海岸において報告さ れている（例えば、 $[8,9] ）$ 。本稿では、日本海沿 岸における沿岸砂州の組織的変動特性に関する 研究について、著者らの研究室での取り組みとそ の成果の一部について紹介する。

* 2019.5.7 受付

** 金沢大学理工研究域地球社会基盤学系 $\overline{7} 920-1192$ 石川県金沢市角間町

TEL: (076)234-4609 FAX: (076)234-4644 E-mail: yuhi@se.kanazawa-u.ac.jp 


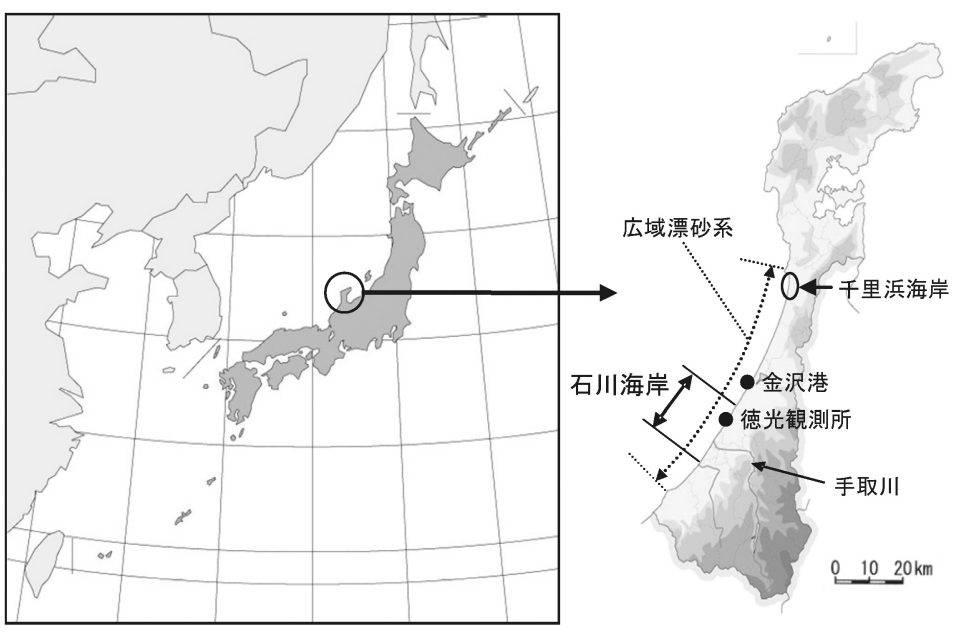

Fig. 1 Locations of Ishikawa Coast and Chirihama Coast.
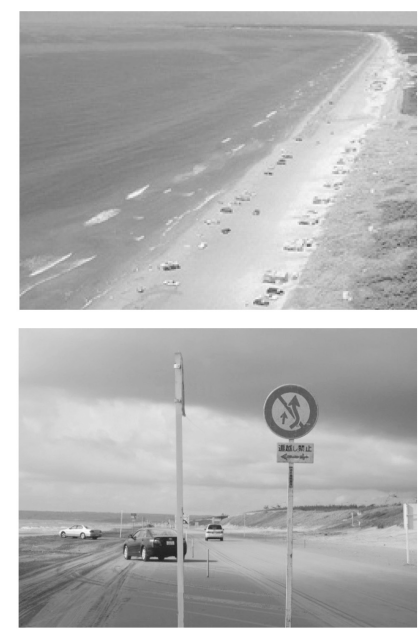

Photo 1 Nagisa Driveway.

\section{2. 対象海岸の概要}

\section{1 石川海岸}

石川海岸は, 石川県南西部に位置し, 日本海に 面した遠浅の砂浜海岸である. 主要な土砂供給源 は石川県手取川であり, 日本海に沿って, 加佐の 岬から能登半島滝崎に渡り約 $75 \mathrm{~km}$ の範囲に広 がる広域流砂系の中央部付近に位置する (Fig. 1)。 本稿で取り扱ら対象領域は, 手取川河口を中心と した沿岸方向 $21.5 \mathrm{~km}$ の範囲亡なる。汀線付近の 代表的な粒径は $0.2 \sim 0.5 \mathrm{~mm}$ 程度である。汀線近 傍から沖合 $1000 \mathrm{~m}$ （水深 $10 \mathrm{~m}$ 相当）付近までの 範囲で多段砂州が発達し, 活発な移動を繰り返し ている。多くの場合、砂州は二段配置であり、10 年程度の時間スケールで周期的に変動する。

金沢港におけるNOWPHAS 波浪観測システム （例えば、[10]）の観測結果の解析[11]によると、 夏期の平均有義波高は $0.5 \mathrm{~m}$ 程度と静穏であるが、 冬期の平均有義波高は $2 \mathrm{~m}$ 程度と高く、年最大有 義波高は 6 $8 \mathrm{~m}$ に達する。潮位変動は $\pm 0.2 \mathrm{~m}$ 程 度と小さいため、汀線近傍における地形変動は主 に波浪の影響を受ける。波による移動限界水深は 9〜 $10 \mathrm{~m}$ 程度と推定されている。

冬季高波浪の㛜しい自然条件に加え、手取川流 域からの土砂供給の減少に伴って、近年、石川海 岸は、長期的な侵食傾向にある[12]。急激な汀線 の後退を受けて、1970 年以降、侵食対策として、 離岸堤や人工リーフなど多くの海岸構造物が建 造された。この結果、現在では、汀線近傍の侵食 は緩和されている[13]。
石川海岸では、国土交通省北陸地方整備局金沢 河川国道事務所により、1960 年以降、深浅測量 が実施されている。筆者らの研究室では、過去 50 年以上の長期に渡る深浅測量結果に基づいて 海底地形変化の解析を進めてきた。本稿第 3 章で は、石川海岸に発達する多段砂州システムの 3 次 元動態の追跡と類型化、周期的变遷過程の定量化 や国内外の他の観測例との比較実証を行った結 果について、その一部を紹介する。

\section{2 千里浜海岸}

千里浜海岸は、石川県手取川を土砂供給源とす る広域流砂系の北端に位置する遠浅の砂浜海岸 である（Fig. 1)。底質の大部分は細砂であり、汀 線近傍における代表的な粒径は $0.15 \mathrm{~mm}$ 前後で ある。水面下では大規模な沿岸砂州が 3 段に発達 し $[14,15]$ 、背後には複列の砂丘を擁して砂州一砂 丘系を構成している。

国内外の多くの砂浜海岸は、重要な観光資源と しての役割を担っている。砂浜での一般車両の走 行が可能な「なぎさドライブウェイ（Photo 1)」 を有する千里浜海岸もその代表的な 1 つである [14]。ドライブウェイを安全に維持・管理するた めには、砂浜幅の確保が必要であるが、千里浜海 岸では、過去 20 年間で最大約 $50 \mathrm{~m}$ もの汀線後退 が報告されるなど、顕著な浜幅縮小が観察されて きた。このため、人工リーフ建設や金沢港浚渫土 砂の海上投入による養浜等の対策が石川県によ り進められている。

千里浜海岸周辺では、2000〜2010 年に渡って、 

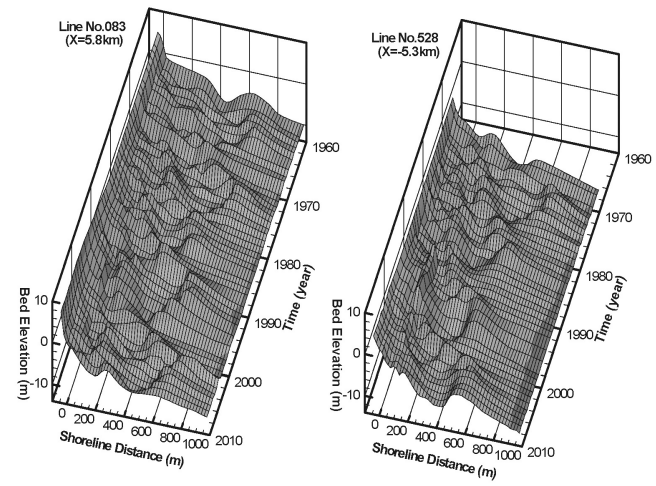

Fig. 2 Examples of long-term variation of cross-shore profiles. Retrieved from Yuhi and Okada [16].

国土交通省金沢河川国道事務所により深浅測量 が実施された。対象地域では、近年、人工リーフ が施工されているが、今回紹介する解析の対象期 間はその施工前となる。第 4 章では、現地観測結 果に基づき、千里浜海岸の多段砂州システムを対 象に、沿岸砂州の形成・移動・消失過程と汀線・ 土砂量変動との関連、平面的な変動特性について 解析・モデル化を行った結果の一部について紹介 する。

\section{3. 石川海岸における沿岸砂州の組織的変動 \\ 3.1 砂州平面形状の遷移 $[16,17]$}

石川海岸では、比高が $5 \mathrm{~m}$ に達するような大規 模な沿岸砂州が発達する[16]。多くの場合砂州は 2 段である。Fig. 2 には、対象領域内で手取川河 口両岸側に位置する 2 つ測線を抜き出して、断 面地形の経年変化を例示した。多段砂州の大規模 な岸沖移動が全期間を通じて周期的に繰り返さ れる様子が確認できる。沿岸砂州の配置を 3 次元 的にプロットした例をFig. 3 に示す。図中の $X=0$ が手取川河口位置に対応する。1970 年には、手 取川河口部で砂州が突出したような形状を取り、 両岸側の砂州は比較的 3 次元性の強い形状を示 している。一方、1974 年に観察された砂州配置 では、1 段目砂州が沖側に移動し、2 段目砂州は 逆に岸向きに移動している。この段階で、右岸側 の砂州は比較的一様、左岸側の砂州配置は 3 次元 的となり、2 $3 \mathrm{~km}$ 程度の波長で汀線から時計回 り方向に傾いた砂州列の雁行配置を示している。 このように、沿岸砂州の平面形状は、緩やかな
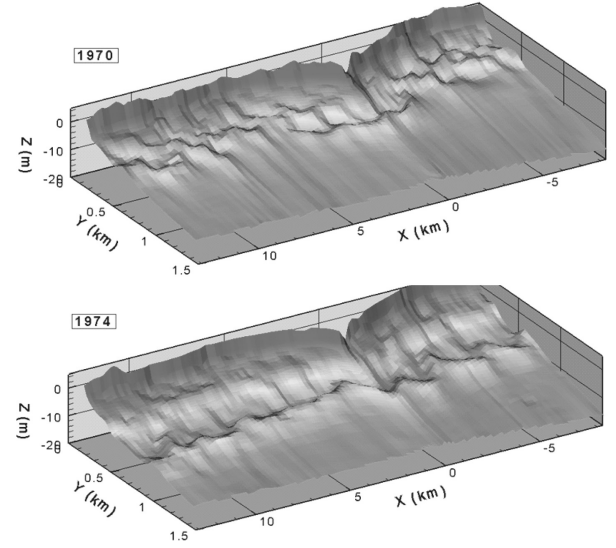

Fig. 3 Examples of three-dimensional configuration of multiple sandbar system. Retrieved from Yuhi and Okada [16].

長弧状、左右対称な三日月状、左右非対称な雁行 配置状など、時間的・空間的にさまざまな変動を 見せるが、全体システムとしては、10 年程度（8 〜 12 年）の再現周期で共通な変動パターンを示 しており、1960〜2010 年の観測期間中に 5 サイ クルの変動が認められた。

石川海岸に発達する多段砂州システムの平面 配置の変遷を特徵付ける代表パターンとして Fig. 4 に例示寸る 4 つの形態が繰り返し確認された。 Fig. 4 は、砂州峯位置および比高（定義を Fig. 5 に示す）をそれぞれプロットの中心位置と大きさ で表し、砂州平面形状と比高の経年変化を表示し たものである。砂州の世代ごとに色分けして表記 しており、観測期間中に観察された第 2 世代砂州 から第 3 世代砂州一の変遷過程に対応する。

1975 年は、最沖砂州群（Bar-2）が雁行配置状 のリズミックな変化を示しつつ、全体としては直 線状に連なる配置である。その背後には次世代の 砂州（Bar-3）が離岸距離 $200 \mathrm{~m}$ 付近に位置して いる。1978 年には、中央部分で最沖砂州が消失 した形へと砂州配置が変化しており、この結果、 中央部分の次世代砂州が沖向き移動と発達を加 速させることとなる。1981 年には、最沖砂州の 消失を受けて、中央部で次世代砂州が発達・沖向 きに移動している。この段階では両側に前世代の 砂州が残存し、その背後に次世代の砂州が位置す るため、平面形としては 2 世代の砂州が分岐して 不連続的に配置される。1983 年には、両側に残 

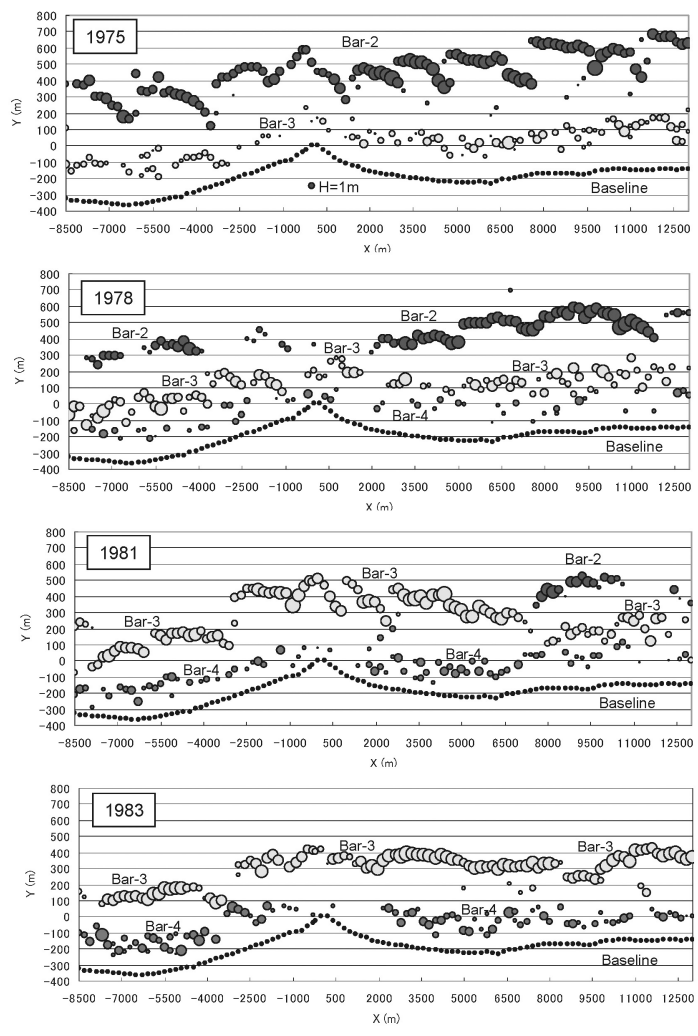

Fig. 4 An example of observed inter-annual transition of multiple bar configuration at Ishikawa Coast. Retrieved from Yuhi [17].

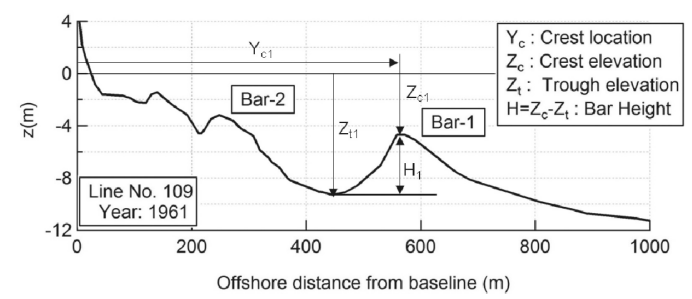

Fig. 5 Definition of sandbar properties.

存していた前世代砂州が消失し、次世代砂州が沖 向きに移動して、中央部の不連続性が緩和された 配置へと変化している。両側の砂州の消失は中央 部側から外側に向けて順に進行していく。消失時 の岸沖移動方向は岸向きである。この後、1975 年と類似した状態へ移行する。

\section{2 個々の砂州の移動・発達・消失特性[17]}

解析期間中に観察された計 6 世代の砂州につ いて、平均離岸距離（測量基点からの距離）と平

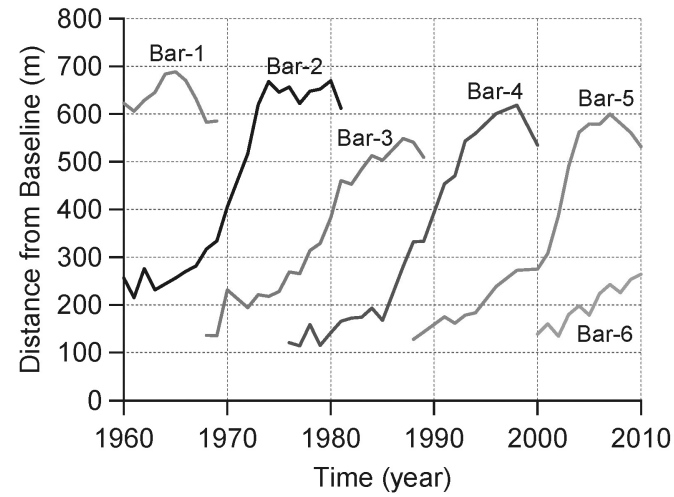

Fig. 6 Observed inter-annual variation in the cross-shore location of individual bar at Ishikawa Coast. Retrieved from Yuhi and Okada [17].

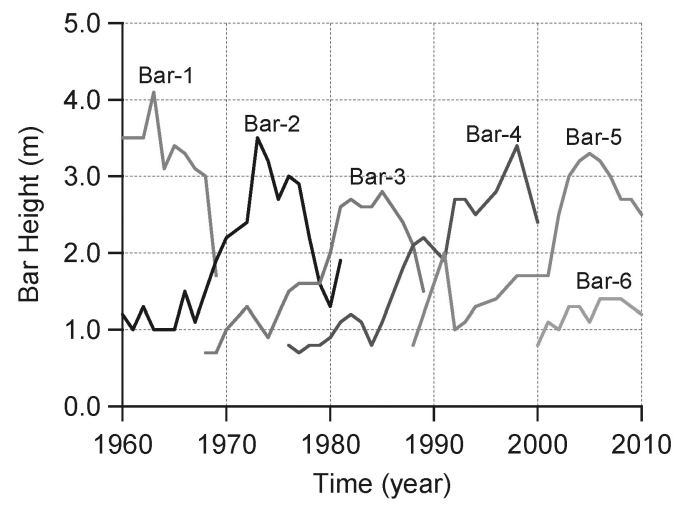

Fig. 7 Observed inter-annual variation in the height of individual bar at Ishikawa Coast. Retrieved from Yuhi and Okada [17].

均比高（砂州峯と谷の高低差、Fig. 5）の変遷を 解析した例をFig. 6 および Fig. 7 亿示す。長期的 な海岸侵食の影響下で、砂州の移動範囲は特に侵 食の影響が顕著であった 1980 年代（第 3 世代） で岸寄りに縮小し、その後回復する傾向にある。 砂州の移動形態は以下に示す 4 つのステージ で特徴づけられる。(1) 形成 : 離岸距離 $150 \mathrm{~m}$ 付 近で形成され、離岸距離 $200 \sim 300 \mathrm{~m}$ の位置に向 けて、約 $10 \mathrm{~m} /$ 年の速度で緩やかに沖向きに移動 する。（2）沖向き移動と発達 : 離岸距離 $550 \mathrm{~m}$ 付 近へ向けて、平均約 $60 \mathrm{~m} /$ 年の速度で、離岸距離 500〜600 m の位置一向けて急速に沖向き移動す る。この段階で比高も大きく発達する。（3A）沖 向き減衰 : $15 \mathrm{~m} /$ 年に移動速度を減じつつ $70 \mathrm{~m}$ 程 
Table 1 Comparison of NOM characteristics with other sites. Retrieved from Yuhi and Okada [17].

\begin{tabular}{ccccc}
\hline Location & Country & $\begin{array}{c}\text { Total Life } \\
\text { Span }(\mathrm{yr})\end{array}$ & $\begin{array}{c}\text { Return } \\
\text { Period }(\mathrm{yr})\end{array}$ & $\begin{array}{c}\text { Migration } \\
\text { Rate }(\mathrm{m} / \mathrm{yr})\end{array}$ \\
\hline Ishikawa & \multirow{2}{*}{ Japan } & $21-24$ & $9-12$ & $45-85$ \\
Hasaki & 1 & 1 & 190 \\
\hline Egmond & & $15-20$ & 15 & 30 \\
Zandvoort & \multirow{2}{*}{ Netherlands } & 10 & $3-4$ & $60-70$ \\
Katwijk & & $6-8$ & $4-5$ & 60 \\
Tershelling & & 20 & $7-8$ & 50 \\
\hline Duck & U.S.A. & $4-5$ & $3-7$ & $60-70$ \\
\hline Wanganui & New Zealand & $2-5$ & $1-2$ & $100-200$ \\
\hline
\end{tabular}

度さらに沖向き移動する。比高は増加から減少に 転じるか、あるいは、同程度で推移する傾向が見 られた。(3B) 岸向き減衰: 沿岸方向に切断され、 沿岸長及び比高を減じつつ、緩やかに岸向きに移 動して消失する。砂州比高の変動は離岸距離と密 接に関係し、世代間の規模の変遷も移動範囲の増 減と対応寸る。砂州比高は形成期で $1 \sim 1.5 \mathrm{~m}$ 、発 達期で最大 3 $4 \mathrm{~m}$ に達した後、 $1.5 \mathrm{~m}$ 程度まで減 衰して消失する。サイクルの再現周期は 9-12 年、 個々の砂州が形成されてから消失するまでのラ イフスパンは 20 年以上に達する。

\section{3 国内外の観測事例との比較 $[16,17]$}

石川海岸で観察された組織的な多段砂州変動 の特性は、従来世界数地点で報告されてきた NOM 現象と基本的に共通である。ただし、減衰・ 消失段階において、岸向きの移動減衰ステージが 存在し、ライフスパン中に占める減衰期間の割合 が大きいこと、また、3 次元性の発現が大きな役 割を占めることが特徴的である。砂州の沖向き移 動速度や再現周期、存在期間について比較した結 果を Table 1 に示寸。なお、移動速度として、第 2 ステージの值を示している。石川海岸における $\mathrm{NOM}$ パラメータの值は、存在期間や再現周期が 長めであるが、移動速度は他の多くのサイトと同 程度の値を示している。

\section{4. 千里浜海岸における沿岸砂州の組織的変動}

\section{1 多段砂州の周期変動特性 $[18,19]$}

千里浜海岸における断面地形々その経年変化 も、多段砂州の存在とその活発な移動により特徵 づけられる。Fig. 8 に例示した断面地形変化の上 下図を比較すると、約 4 年サイクルで周期変動が 繰り返されていることが明瞭な形で確認できる。
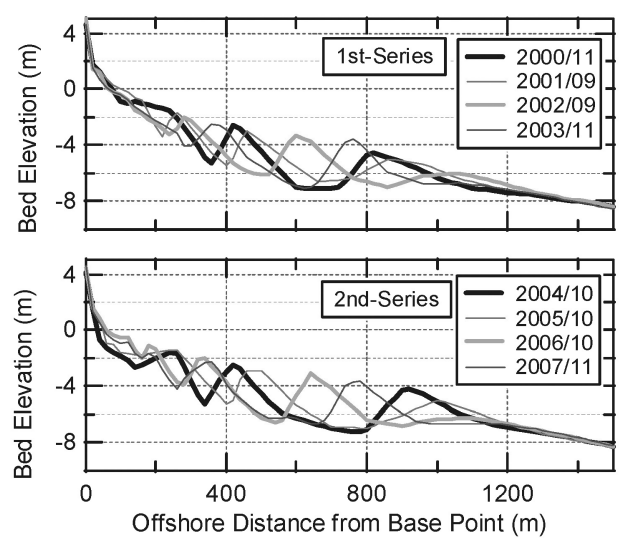

Fig. 8 Examples of cyclic migration of multiple bar system at Chirihama Coast. Retrieved from Yuhi et al. [18]

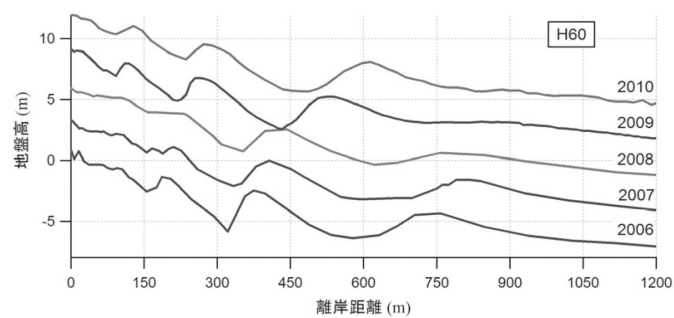

(a) Temporal variation of profile at a fixed transect

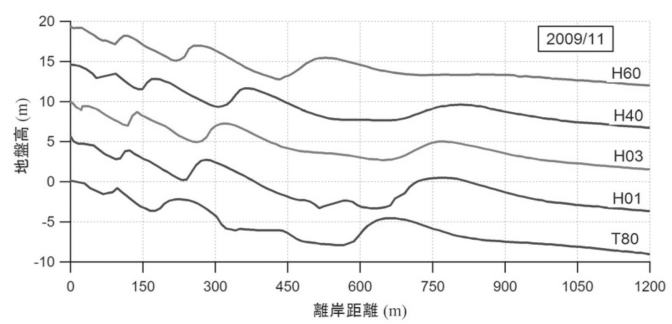

(b) Alongshore variation of profile at a fixed time.

Fig. 9 Comparison of temporal and spatial variations of bar configuration at Chirihama Coast.

Retrieved from Yuhi et al. [19].

砂州比高の最大值は、 $4 \mathrm{~m}$ 以上に達している。

千里浜海岸および石川海岸は、両者ともに手取 川を起源とする広域流砂系の一部であり、波浪・ 潮汐に代表される自然外力特性もおよそ同様で あるが、砂州動態に関してはそれぞれの特徵が現 れる。まず、砂州配置としては、千里浜海岸では 3 段、石川海岸は 2 段が代表的である。また、消 失段階において、石川海岸では砂州が岸向きに移 
動して減衰するのに対し、千里浜海岸では砂州は 沖向きに移動・消失していく。周期変動の再現期 間についてみると, 千里浜海岸は 4、5 年程度で あるのに対し、砂州の滞留・消失期間の長い石川 海岸では 10 年程度と 2 倍程度の差が見られる。 さらに、3 次元変動が特徵的な石川海岸と異なり、 千里浜海岸で観察されるNOM では、沿岸方向の 砂州形状は一様に近く、砂州移動は準 2 次元的に 進行する。千里浜海岸における砂州配置の時間変 化と空間変化を対比すると（Fig. 9)、両者は類似 した特徵を有し、砂州変動の時間変化と沿岸変化 に密接な関連が存在することが推察できる。

\section{2 岸沖土砂輸送 - 汀線 - 土砂量変動との関係} [20]

続いて、千里浜海岸および隣接する高松海岸で 観察された多段砂州システムの周期的沖向移動 に伴う変動成分を抽出し、経験的固有関数法

(EOF) 解析を適用して、砂州配置変動の主要モ 一ドや岸沖漂砂・土砂量変動との関係について解 析を行った結果の一部を紹介する。

EOF 解析の結果、沿岸砂州の周期的沖向移動に 伴う地形変動は、EOF 第 1、第 2 モードの組合せ

(zb12) で良く表現された。この 2 つのモードの 時間固有関数は互いに約 $1 / 4$ 周期ずれた形で周期 変動を繰り返すことから、砂州移動の 1 サイクル 間に第 1 、第 2 モードが符号を変えつつ交互に支 配的となる。その結果、砂州移動に伴う地形変動 は、Fig. 10 に示される 4 つの型（+E1, +E2, -E1,

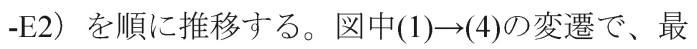
沖砂州が沖向移動しながら減衰し、対応して沖か ら 2 段目の砂州が沖向に移動発達する構造が明確 に見て取れる。この測線の場合、砂州が最も発達 するのは、離岸距離 $500 \mathrm{~m}$ 付近である。離岸距離 がさらに大きくなると減衰領域となり、1200 m より沖側には変動は及ばない。

断面内土砂量の保存式を積分することにより、 砂州変動の基本モード（第 1 、第 2 モードの組合 せ $z b 12 ）$ に対応する岸沖漂砂量分布の固有モード

（qb12）を算出した例をFig. 12 に示す。千里浜周 辺海岸においては、砂州峯位置の移動（形状とし ての移動）は、砂州のライフサイクルを通じて常 に沖向きであるが、対応する土砂移動方向は沖向 き・岸向きの両方に変化し得る。たとえば、Fig. 12 に示した砂州移動との対応例では、最沖砂州の沖 向き移動は上記 $(2) \rightarrow(3)$ 間では沖向き漂砂に起因
し、沖側から 2 段目となる砂州の沖向き移動・発 達には沖側トラフからの岸向き土砂移動が寄与 する。汀線近傍では、砂州移動ステージに応じて、 前浜との土砂授受が発生し、断面内土砂量は周期 的変動を示すが、1 サイクル経過すると土砂量は およそ元の状態に戻る。この意味で砂州の周期的 沖向き移動は土砂量の中期変動に関与するが、長 期的な土砂量変動には寄与しないと推定される。

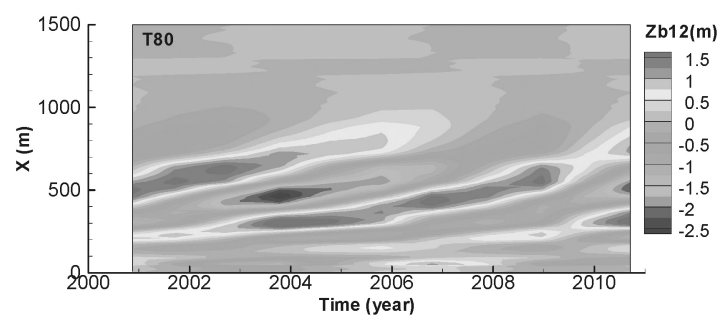

Fig. 10 Examples of bar migration modes. Retrieved from Yuhi et al. [20].

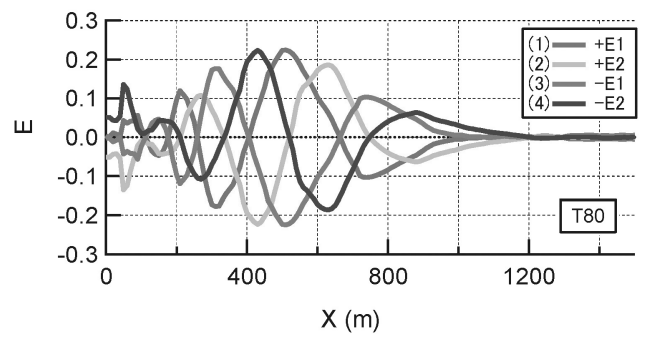

Fig. 11 Transition among the four representative modes of net offshore bar migration. Retrieved from Yuhi et al. [20].
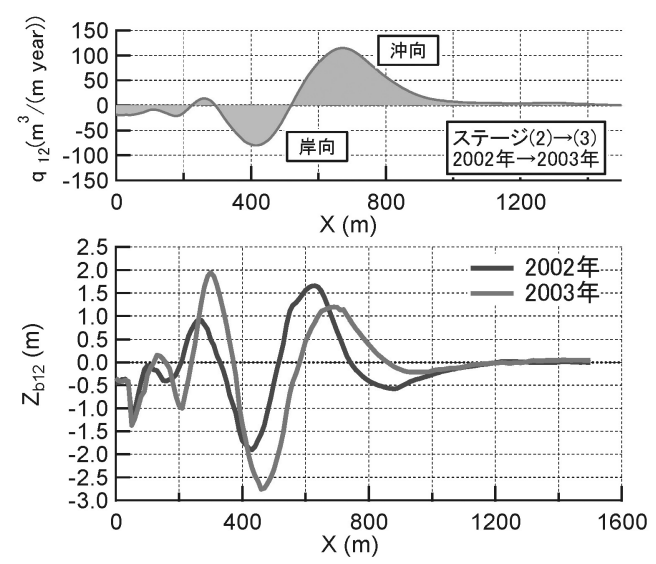

Fig. 12 Comparison between profile change $\left(z_{b 12}\right)$ and cross-shore sediment transport rate $\left(q_{b 12}\right)$. Retrieved from Yuhi et al. [20]. 


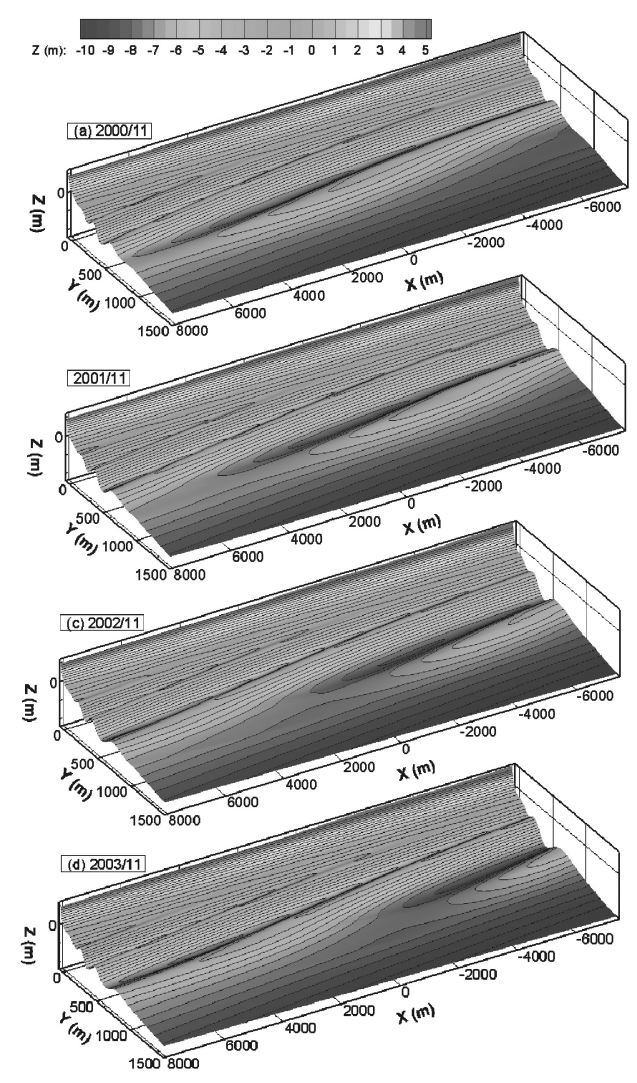

Fig.13 Transition of three-dimensional bar configuration reproduced by an empirical parametric model. Retrieved from Yuhi et al. [19].

\section{4 パラメトリックモデルによる表現[19, 21]}

本節では, 現地観測データから経験的固有関数 法により抽出された砂州移動の固有モード情報 を活用することで、砂州の周期移動に伴う 3 次元 地形の時空間変動を簡潔に表現できる経験的モ デルを構築し、その適用性や砂州配置の変遷特性 について検討を行った結果を示す。

まず、各測線について基準地形と変動成分を分 離した後に、変動成分の EOF 解析を行って砂州 移動に対応する固有モードを抽出し、その振幅・ 位相特性を余弦関数、指数関数、1 次関数等の簡 易な関数で近似して各測線上の砂州移動を表現 した。次に測線別の砂州変動パラメータを沿岸方 向に最小自乗近似で補間して変動成分の平面構 造を決定し、基準地形成分と合わせて、3 次元地

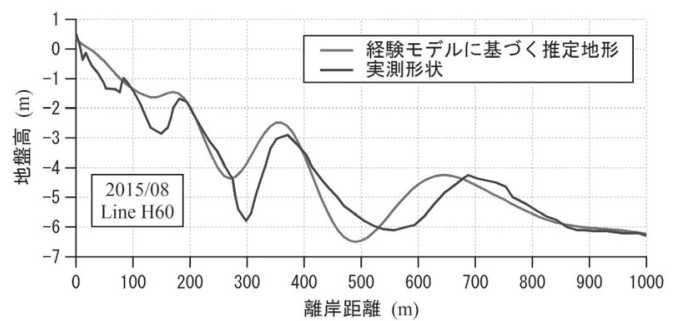

Fig. 14 A comparison between the surveyed profile and model prediction. Retrieved from Yuhi et al. [19].

形変動をモデル化し、その特性を検討した。

構築したモデルにより再現された 3 次元地形変 動のパターンを Fig. 13 に示す。最沖砂州の消失 後、岸側の砂州が沖向き移動・発達を繰り返す 様子や、一連のステージ変化が北から南に進行す る平面的変遷過程の特徴が良く再現されている。 さらに、モデル構築対象期間から 5 年後の地形を 推定し、実測と比較した例を Fig. 14 に示した。 この例では、砂州配置や頂部高等について良好な 一致が見られた。さらに、砂州移動の時間変化と 沿岸変化の相互関係について検討した結果、沿岸 位置を固定して観測される地形の時間変化と時 間を固定して沿岸位置を移動させて観察される 地形の空間変化は可換的特性を示すことを確認 することができた。

\section{5. 結 言}

本稿では、日本海に面した石川海岸および千里 浜海岸で観測された大規模かつ組織的な多段砂 州の周期的移動の特性を対象に、著者らの研究室 におけるこれまでの研究成果の一部を紹介し、そ の特徵を総括することを試みた。

長期かつ大規模な沿岸砂州の時空間変動につ いては、組織的移動に関わる内部機構の詳細解明 とそのモデル化、作用外力のとの相互作用、構造 物設置等の人為的インパクトの影響など未解明 な点も多く残されているのが現状である。今後も 引き続き、これらの研究課題の解明を進めていく 予定である。

\section{謝 辞}

本稿にて紹介した研究の一部は日本学術振興 会科学研究費補助金（16K06505、18K04363）の 
補助を受けた。解析に用いた測量データは、国土 交通省北陸地方整備局金沢河川国道事務所に提 供いただいた。また、一連の研究の推進にあたつ ては金沢大学水工学研究室の学生諸氏から多く の助力をいただいた。ここに記して謝意を表する。

\section{参考文献}

[1] Wijnberg, K. M. and Kroon, A., Barred Beaches, Geomorphology, Vol.48, 103-120 (2002).

[2] Greenwood, B., Bars, In: Schwartz, M. (ed.), Encyclopedia of Coastal Science, 120-129, Springer, The Netherlands (2005).

[3] Ruessink, B. G. and Kroon, A., The Behavior of a Multiple Bar System in the Nearshore Zone of Terscheeling, the Netherlands: 1965-1993, Marine Geology, Vol. 121, 187-197 (1994).

[4] Wijnberg, K. M. and Terwindt, J. H. J., Extracting Decadal Morphological Behavior from High-Resolution, Long-Term Bathymetric Surveys along the Holland Coast Using Eigenfunction Analysis, Marine Geology, Vol.26, 301-350 (1995).

[5] Ruessink, B. G. and Terwindt, J. H. J., The Behavior of Nearshore Bars on the Time Scale of Years: a Conceptual Model, Marine Geology, Vol. 163, 289-302 (2000).

[6] Kuriyama, Y., Medium-Term Bar Behavior and Associated Sediment Transport at Hasaki, Japan. Journal of Geophysical Research, Vol. 107(C9), 3132 (2002) doi:10. 1029/2001JC000899.

[7] Shand, R. D., Bailey, D. G. and Shepherd, M. J., An Inter-Site Comparison of Net Offshore Bar Migration Characteristics and Environmental Conditions, Journal of Coastal Research, Vol.15, (3), 750-765 (1999).

[8] Yuhi, M. and Okada, M., Long-Term Field Observations of Multiple Bar Properties on an Eroding Coast, Journal of Coastal Research, SI No. 64, 860-864 (2011).

[9] Yuhi, M., Matsuyama, M. and Hayakawa, K., Sandbar Migration and Shoreline Change on the Chirihama Coast, Japan, J. Marine Science and Engineering, Vol. 4(2) (2016) doi: 10. 3390/jmse4020040.

[10] Nagai, T., Sugahara, K., Hashimoto, N., Asai, T., Higashiyama, S. and Toda, K., Introduction of Japanese NOWPHAS System and Its Recent Topics, Proceedings of International Conference on Hydro-Technical Engineering for Port and Harbor Construction (HYDRO-PORT'94), PHRI, 67-82 (1994).
[11] Nguyen, T. C. and Yuhi, M., Long-Term Variation of Wave Characteristics on the Kaetsu Coast, Japan, Journal of Japan Society of Civil Engineers, Ser. B3 (Ocean Engineering), Vol. 71(2), I_359-I_364 (2015).

[12] Yuhi, M., Impacts of Anthropogenic Modifications of River Basin on Surrounding Coasts: A Case Study, Journal of Waterway, Port, Coastal and Ocean Engineering, ASCE, Vol. 134 (6), 336-344 (2008).

[13] Yuhi, M., Dang, M. H. and Umeda, S., Comparison of Accelerated Erosion in Riverbed and Downstream Coast by EOF Analysis Over a Decadal Scale, Journal of Coastal Research, SI No. 65, 618-623 (2013).

[14] Ishida, H., Takase, N., Nagahara, H. and Ura, R., Current Status of Erosion Problems on Chirihama Beach and Nagisa Driveway. Proc. Coastal Eng., JSCE, Vol. 31, 355-359 (1984).

[15] Kato, K., On the Relation between Infragravity Waves and Multiple Sandbars. Proc. Coastal Eng., JSCE, Vol. 31, 441-445 (1984).

[16] Yuhi, M. and Okada, M., Three-Dimensional Cyclic Behaviors of Multiple Sandbars on the Ishikawa Coast, Japan, Journal of JSCE, Ser. B2 (Coastal Engineering), Vol. 68, 641-645 (2012).

[17] Yuhi, M., Characteristics of Inter-Annual Bar Migration on the Ishikawa Coast, Japan, Journal of JSCE, Ser. B2 (Coastal Engineering), Vol. 69, 641-645 (2013).

[18]Yuhi, M., Umeda, S., Hayakawa, K., Kawashima, H., Ura, T. and Ishida, H., Basic Characteristics of Shoreline Change and Bar Migration on Chirihama Beach, Japan, Journal of JSCE, Ser. B2 (Coastal Engineering), Vol. 66, 561-565 (2010).

[19] Yuhi, M., Yamakoshi, T. and Umeda, S., Three-Dimensional Parametric Model for Sandbar Migration on the Chirihama and Takamatsu Coast, Ishikawa, Japan, Journal of JSCE, Ser. B2 (Coastal Engineering), Vol. 73, 763-768 (2017).

[20] Yuhi, M., Ogura, T. and Matsuyama, M., Cross-Shore Sediment Transport and Sediment Volume Change during Systematic Migration of Multiple Sandbars, Journal of JSCE, Ser. B2 (Coastal Engineering), Vol. 71, 643-648 (2015).

[21] Yuhi, M., Umeda, S., Yamakoshi, T. and Okabe, Y., A Parametric Model for Systematic Migration of Sandbars on the Chirihama and Takamatsu Coast, Ishikawa, Japan, Journal of JSCE, Ser. B2 (Coastal Engineering), Vol. 72, 673-678 (2016). 